\title{
Genetic variability and divergence among Italian populations of common ash (Fraxinus excelsior $\mathbf{L}$.)
}

\author{
Diana Ferrazzini, Ignazio Monteleone, Piero Belletti* \\ University of Turin, DIVAPRA Plant Genetics and Breeding, via Leonardo da Vinci 44, 10095 Grugliasco, Italy
}

(Received 4 April 2006; accepted 6 July 2006)

\begin{abstract}
The level of genetic variation throughout the Italian range of common ash (Fraxinus excelsior L.) was estimated using six microsatellite markers. High levels of allelic diversity was detected. The levels of expected heterozygosity for each of the populations ranged from 0.726 to 0.871 , with an average of 0.798 , and indicated that populations have a high level of genetic variation. A general and significant homozygote excess was found at most loci in all populations, with an overall mean $F_{\text {IS }}$ of 0.284 . Possible explanations for such situations are discussed. Only $4.9 \%$ of the total diversity was attributable to differentiation among populations. Although divergence among pedo-climatic regions explained only a small part of the variance it was possible to observe some partial clustering of populations belonging to the same regions. The contribution of the results in relation to the definition of the most appropriate strategies to collect forest reproductive material is discussed.
\end{abstract}

genetic variation / microsatellite / population differentiation / seed zone designation / Fraxinus excelsior

Résumé - Variabilité génétique et différenciation entre populations italiennes de frêne commun (Fraxinus excelsior L.). Le niveau de variation génétique dans l'aire de distribution naturelle du frêne commun (Fraxinus excelsior L.) en Italie a été estimé à l'aide de six marqueurs microsatellite. Des niveaux élevés de diversité allélique ont été détectés. L'hétérozygotie théorique varie de 0,726 à 0,871 , avec une moyenne de 0,798 , ce qui indique que les populations ont un niveau élevé de variation génétique. Un excès général et significatif de l'homozygotie a été trouvé pour la plupart des loci dans toutes les populations, avec une moyenne globale $F_{\text {IS }}$ de 0,284. Des explications possibles pour de telles situations sont proposées. Seulement $4,9 \%$ de toute la diversité est attribuable à la différenciation entre populations. Bien que la divergence entre régions pédo-climatiques explique une petite partie de la variation, il est possible d'observer des regroupements partiels de populations appartenant aux mêmes régions. La contribution de ces résultats à la définition des stratégies les plus appropriées pour rassembler le matériel forestier de reproduction est discutée.

diversité génétique / microsatellite / différenciation entre populations / région de provenance / Fraxinus excelsior

\section{INTRODUCTION}

Forest trees are non-mobile and long-lived organisms which grow under environmental conditions that are heterogeneous in time and space. Moreover, they are exposed to many stress factors, most of which are due to human activities: pollution, climate change, habitat fragmentation. In order to survive these threats, and to persist over time, a high adaptive potential is needed: this is mainly determined by the within-species genetic diversity $[4,46]$. Programmes aimed at the conservation of forest genetic resources should address the issue of maintenance of this diversity [21, 31, 35, 47]. To this end, knowledge of genetic variation, as well as information on mating system and pollen and seed dispersal, are of the utmost importance. Molecular markers are now available and can provide us with the relevant means to acquire information on the genetic structure of populations and to study the pattern of distribution of within-species variability. In particular, simple sequence repeats (SSRs, also known as microsatellites) are commonly used in genetic studies of plant populations. SSRs are tandem repeats of short DNA sequences (1 to 6 base pairs); they are highly polymorphic, widely distributed throughout

\footnotetext{
*Corresponding author: piero.belletti@unito.it
}

the genome and codominant. Allelic variation can be detected quickly by the DNA-polymerase chain reaction (PCR) technique.

Common ash, Fraxinus excelsior L., is a postpioneer heliophilous tree species which grows in mixed deciduous forests all over Europe, from the Atlantic Ocean to the Don river and the Caucasian mountains, and from the southern part of Scandinavia to the Mediterranean Sea. It is a colonizing species, often found with a spatially discontinuous distribution in mixtures with other trees. However, when ecological conditions become very favourable it can be encountered in pure stands. The species has a complex mating system, showing variation in sex expression from pure male to pure female individuals, and with all kinds of hermaphroditic intermediates [17,29,37]. Pollen and fruits (samaras) are wind-dispersed. According to fossil pollen data obtained by Huntley and Birks [26], the species expanded in the Early Holocene from the northern Apennine and from the northern and north-western Black Sea coasts. Heuertz et al. [24] also suggested the eastern Alps and Iberian Peninsula as further refuge areas.

A number of research groups have recently undertaken studies on this species all over Europe $[1,5,6,10,22$, 23, 25, 27, 29], and several European Union projects have 
been devoted to the ash species native to Europe, among which FRAXIGEN (Defining European Ash Populations for Conservation and Regeneration [17]) and RAP (Improving Ash Productivity for European needs by testing, propagation and promotion of improved genetic resources [http://www.teagasc.ie/advisory/forestry/rap/index.htm]). The biological features, for instance colonizing behaviour, spatial distribution and mating system of Fraxinus species make them models of great interest for population genetics studies.

Forestry management of common ash in Europe has shown increased interest in the last decades, mainly due to the recognition of its high economic value as quality timber producer [38]. The species is usually propagated through natural regeneration. Sometimes, however, afforestation and reforestation programmes are carried out using reproductive material produced in nursery. In these cases, the genetic quality of the used material is of utmost importance, both to guarantee a good chance of success for afforestation and also to preserve the natural genetic variability of the species [31]. Forests from southern Europe constitute highly valuable genetic resources of noble hardwood, among which are Fraxinus spp. [11]. The most appropriate strategy to preserve the genetic resources of these species is the establishment of in situ reservoirs, within the frame of forestry management.

The Italian Government has recently issued act No. 386/2003, that implements the European Council Directive 1999/105/CE, concerning the marketing of forest reproductive material. One of the most important feature of the act is the definition of Region of Provenance as "...the area or group of areas subjected to sufficiently uniform ecological conditions in which stands or seed sources showing similar phenotypic or genetic characters are found...". The identification of these areas plays a basic role for a rational management of activities linked with forest trees propagation, including afforestation and in situ genetic preservation.

In this study we defined the structure of genetic variation throughout the distribution of common ash in Italy. Genetic differentiation was estimated for three different geographical scales (between individuals within populations; between populations within pedo-climatic regions, and between regions) using six nuclear microsatellite loci. Further objectives were to evaluate whether the distribution of genetic variability is influenced by pedo-climatic characteristics of the area where populations grow, and to find out the biological characteristics useful for conservation management, such as the level of inbreeding. This information is of basic importance for the definition of Italian Regions of Provenance for common ash, although a deeper knowledge of the ecological characteristics of the areas of the study, such as vegetational and phytogeographical data, is also needed.

\section{MATERIALS AND METHODS}

\subsection{Ecological data}

Pedo-climatic characteristics of the study area were inferred from existing cartography, namely the Soil Regions of Europe developed by the European Commission [12]. This document reports the climate types that are present in Europe according to the CLIMWAT database, and joins regions according to their climate, geology and pedology characteristics.

\subsection{Plant material}

Thirty-one natural populations of Fraxinus excelsior were chosen within the natural area of diffusion of the species in Italy (northern part of the country). All the populations belong to mixed forests, in which common ash is never the dominant species, although a certain variation among stands according to ecological conditions could be detected (Tab. I and Fig. 1). In some stands (namely the ones located at the eastern part of the area under study) we also detected the presence of Fraxinus angustifolia. This is a species closely related with common ash, and the occurrence of interspecific hybrids has been documented [17]. To avoid sampling F. angustifolia and/or hybrids, we collected only terminal buds black in colour and with flattened nodes forming a "snake-head". The period of sampling (winter or early spring) precluded using more valid criteria of species differentiation, such as gender of inflorescence and fructification type [17]. Furthermore, we did not sample common ash individuals in proximity of $F$. angustifolia plants. For purposes of the analysis the 31 populations were divided into groups that reflect natural structuring: the most natural way of objectively structuring populations was to follow the subdivision of the area in pedo-climatic regions, according to the data from European Commission [12]. Buds or young leaves were sampled from about 30 non-adjacent trees in each population, randomly chosen over a 5 to 10 ha area. After collection, buds and young leaves were frozen at $-20{ }^{\circ} \mathrm{C}$ until DNA extraction.

\subsection{Microsatellite analysis}

Total DNA was extracted from about $100 \mathrm{mg}$ frozen leaves or 2-3 buds using Lefort-Douglas method [27]. Six primers pairs of microsatellite loci, which had previously been shown to display easy to read band patterns and a high degree of polymorphism in Fraxinus excelsior, were used for the polymerase chain reactions $[6,22,27,29]$ : FEMSATL4, FEMSATL10, FEMSATL11, FEMSATL12, FEMSATL16, FEMSATL19.

The PCR reactions were performed in a mix containing $2.5 \mathrm{mM}$ $\mathrm{MgCl}_{2}, 1$ unit of Taq polymerase (Promega) in 1X Promega buffer, $0.2 \mu \mathrm{M}$ of each primer, $0.2 \mathrm{mM}$ of dNTP mix and approximately $20 \mathrm{ng}$ of template DNA, adding deionised water to a total reaction volume of $20 \mu \mathrm{l}$. After an initial denaturing step at $95{ }^{\circ} \mathrm{C}$ for $4 \mathrm{~min}$, amplification comprised 35 cycles of $1 \mathrm{~min}$ at $94{ }^{\circ} \mathrm{C}, 1 \mathrm{~min}$ at either $52^{\circ} \mathrm{C}$ (FEMSATL4, FEMSATL11, FEMSATL12, FEMSATL16, FEMSATL19) or $55{ }^{\circ} \mathrm{C}$ (FEMSATL10) and $2 \mathrm{~min}$ at $72{ }^{\circ} \mathrm{C}$. Final elongation lasted $10 \mathrm{~min}$ at $72{ }^{\circ} \mathrm{C}$. PCR reactions were performed on a Perkin Elmer GeneAmp ${ }^{\circledR}$ PCR System 9600 thermocycler. The forward sequence of each primer pair was labelled with a fluorescent dye (M-Medical S.r.l. and MWG-Biotech AG) at its 5'end: IRD 800 for FEMSATL4, FEMSATL1 1 and FEMSATL16 and IRD 700 for FEMSATL10, FEMSATL12 and FEMSATL19. Electrophoresis and detection of PCR products were carried on a denaturing polyacryalmide gel $(6 \%)$ using a sequencer (model DNA 4200 Sequencer LI-COR ${ }^{\circledR}$ Biotechnology). Gels were run for $2 \mathrm{~h}$ at $2000 \mathrm{~V}$ in TBE $1 \mathrm{X}$ buffer. Determination of polymorphism was obtained using a marked standard of known molecular weight (50-350 bp). Data were collected by e-Seq software (DNA Sequencing and Analysis Software). 
Table I. Details of site and stand characteristics of common ash populations from Italy which were sampled for the study. Soil Region: $34.3=$ Leptosol (parent material association: calcareous sedimentary rocks), 37.1 = Leptosol - Podzol - Cambisol (igneous and metamorphic rocks), 59.7 = Cambisol - Leptosol (Mesozoic sedimentary rocks), $60.4=$ Cambisol - Luvisol (Mesozoic sedimentary rocks), $61.1=$ Cambisol Regosol (tertiary sedimentary rocks), $70.1=$ Luvisol - Cambisol - Gleysol (glacial deposits). Climate: $33=$ sub-oceanic temperate, $37=$ sub-continental hot-temperate, 38 = mountain temperate (European Commission, 1999).

\begin{tabular}{|c|c|c|c|c|c|c|c|}
\hline Population & Region & Location & $\begin{array}{l}\text { Elevation } \\
\text { (m a.s.1.) }\end{array}$ & Type of stand & $\begin{array}{l}\text { Proportion of common } \\
\text { ash in the canopy }\end{array}$ & Soil region & Climate \\
\hline 1. Lame del Sesia & Piedmont & $45^{\circ} 26^{\prime} \mathrm{N}, 8^{\circ} 23^{\prime} \mathrm{E}$ & 150 & Mixed plan forest & 30 & 70.1 & 33 \\
\hline 2. Partecipanza & Piedmont & $45^{\circ} 14^{\prime} \mathrm{N}, 8^{\circ} 20^{\prime} \mathrm{E}$ & 150 & Oak and hornbeam forest & 20 & 70.1 & 33 \\
\hline 3. Spazzacamini & Piedmont & $45^{\circ} 46^{\prime} \mathrm{N}, 8^{\circ} 16^{\prime} \mathrm{E}$ & 300 & Oak and hornbeam forest & 30 & 70.1 & 33 \\
\hline 4. Merlino & Piedmont & $44^{\circ} 47^{\prime} \mathrm{N}, 7^{\circ} 44^{\prime} \mathrm{E}$ & 250 & Oak and hornbeam forest & 15 & 70.1 & 33 \\
\hline 5. Pian delle Gorre & Piedmont & $44^{\circ} 19^{\prime} \mathrm{N}, 7^{\circ} 41^{\prime} \mathrm{E}$ & 1000 & Mixed mountain forest & 40 & 60.4 & 38 \\
\hline 6. Oncino & Piedmont & $44^{\circ} 41^{\prime} \mathrm{N}, 7^{\circ} 11^{\prime} \mathrm{E}$ & 1300 & Beech forest & 45 & 37.1 & 38 \\
\hline 7. Valle Divedro & Piedmont & $46^{\circ} 16^{\prime} \mathrm{N}, 8^{\circ} 19^{\prime} \mathrm{E}$ & 800 & Mixed mountain forest & 40 & 37.1 & 38 \\
\hline 8. Valle Bormida & Liguria & $44^{\circ} 24^{\prime} \mathrm{N}, 8^{\circ} 16^{\prime} \mathrm{E}$ & 400 & Chestnut forest & 10 & 60.4 & 38 \\
\hline 9. Valle Tanaro & Liguria & $44^{\circ} 05^{\prime} \mathrm{N}, 7^{\circ} 48^{\prime} \mathrm{E}$ & 750 & Mixed broadleaves mountain forest & 30 & 60.4 & 38 \\
\hline 10. Archesane & Lombardy & $45^{\circ} 39^{\prime} \mathrm{N}, 10^{\circ} 37^{\prime} \mathrm{E}$ & 1000 & Beech forest & 40 & 34.3 & 38 \\
\hline 11. Ponteranica & Lombardy & $45^{\circ} 44^{\prime} \mathrm{N}, 9^{\circ} 39^{\prime} \mathrm{E}$ & 450 & Mixed broadleaves forest & 25 & 34.3 & 38 \\
\hline 12. S. Pellegrino & Lombardy & $45^{\circ} 50^{\prime} \mathrm{N}, 9^{\circ} 40^{\prime} \mathrm{E}$ & 500 & Maple and ash forest & 50 & 34.3 & 38 \\
\hline 13. Val Masino & Lombardy & $46^{\circ} 13^{\prime} \mathrm{N}, 9^{\circ} 38^{\prime} \mathrm{E}$ & 950 & Mixed mountain forest & 20 & 37.1 & 38 \\
\hline 14. Corni di Canzo & Lombardy & $45^{\circ} 51^{\prime} \mathrm{N}, 9^{\circ} 16^{\prime} \mathrm{E}$ & 750 & Beech forest & 25 & 34.3 & 38 \\
\hline 15. Valle Sella & Trentino & $46^{\circ} 03^{\prime} \mathrm{N}, 11^{\circ} 27^{\prime} \mathrm{E}$ & 1000 & Mixed mountain forest & 20 & 37.1 & 38 \\
\hline 16. Valle Mocheni & Trentino & $46^{\circ} 04^{\prime} \mathrm{N}, 11^{\circ} 14^{\prime} \mathrm{E}$ & 1050 & Mixed mountain forest & 10 & 37.1 & 38 \\
\hline 17. Contrada Sorto & Venetia & $45^{\circ} 39^{\prime} \mathrm{N}, 11^{\circ} 18^{\prime} \mathrm{E}$ & 750 & Maple, ash, hornbeam forest & 25 & 34.3 & 38 \\
\hline 18. Broz & Venetia & $46^{\circ} 08^{\prime} \mathrm{N}, 12^{\circ} 25^{\prime} \mathrm{E}$ & 1000 & Spruce forest & 15 & 34.3 & 38 \\
\hline 19. Sedico & Venetia & $46^{\circ} 07^{\prime} \mathrm{N}, 12^{\circ} 06^{\prime} \mathrm{E}$ & 400 & Mixed broadleaves forest & 30 & 34.3 & 38 \\
\hline 20. Peaio & Venetia & $46^{\circ} 25^{\prime} \mathrm{N}, 12^{\circ} 15^{\prime} \mathrm{E}$ & 1000 & Spruce forest & 20 & 34.3 & 38 \\
\hline 21. Schivazzi & Venetia & $45^{\circ} 36^{\prime} \mathrm{N}, 11^{\circ} 06^{\prime} \mathrm{E}$ & 1100 & Beech forest & 25 & 34.3 & 38 \\
\hline 22. Fagarè & Venetia & $45^{\circ} 50^{\prime} \mathrm{N}, 11^{\circ} 55^{\prime} \mathrm{E}$ & 250 & Oak and hornbeam forest & 15 & 34.3 & 38 \\
\hline 23. Chianei & Friuli & $46^{\circ} 17^{\prime} \mathrm{N}, 13^{\circ} 05^{\prime} \mathrm{E}$ & 800 & Mixed broadleaves forest & 35 & 34.3 & 38 \\
\hline 24. Ponte Vittorio & Friuli & $46^{\circ} 15^{\prime} \mathrm{N}, 13^{\circ} 30^{\prime} \mathrm{E}$ & 800 & Beech forest & 15 & 34.3 & 38 \\
\hline 25. Preone & Friuli & $46^{\circ} 24^{\prime} \mathrm{N}, 12^{\circ} 52^{\prime} \mathrm{E}$ & 500 & Beech forest & 25 & 34.3 & 38 \\
\hline 26. Alta val Ceno & Emilia & $44^{\circ} 30^{\prime} \mathrm{N}, 9^{\circ} 38^{\prime} \mathrm{E}$ & 650 & Mixed broadleaves and spruce forest & 15 & 59.7 & 37 \\
\hline 27. Monte Valoria & Emilia & $44^{\circ} 31^{\prime} \mathrm{N}, 9^{\circ} 59^{\prime} \mathrm{E}$ & 900 & Beech forest & 20 & 59.7 & 37 \\
\hline 28. Valle Reno & Emilia & $44^{\circ} 10^{\prime} \mathrm{N}, 10^{\circ} 59^{\prime} \mathrm{E}$ & 800 & Beech forest & 25 & 59.7 & 37 \\
\hline 29. S.Anna Pelago & Emilia & $44^{\circ} 12^{\prime} \mathrm{N}, 10^{\circ} 35^{\prime} \mathrm{E}$ & 1000 & Beech and spruce forest & 20 & 59.7 & 37 \\
\hline 30. Campigna & Emilia & $43^{\circ} 57^{\prime} \mathrm{N}, 11^{\circ} 54 \mathrm{E}$ & 1100 & Mixed broadleaves forest & 10 & 61.1 & 37 \\
\hline 31. Abetone & Tuscany & $44^{\circ} 09^{\prime} \mathrm{N}, 10^{\circ} 40^{\prime} \mathrm{E}$ & 1300 & Beech forest & 30 & 59.7 & 37 \\
\hline
\end{tabular}

\subsection{Data analysis}

Population genetic parameters were estimated using the Genepop 3.4 software (an updated version of Genepop 1.2 described by Raymond and Rousset [39]). The following statistics of genetic variation within populations were computed as average over loci: mean number of alleles per locus $(N)$, average observed heterozygosity $\left(H_{\mathrm{o}}\right)$ and average gene diversity $\left(H_{\mathrm{e}}\right.$, according to Nei [33]). Average allelic richness $(R)$, a measure independent of the sample size, was estimated using the program Fstat version 2.9.3 [19]. Genepop was used for testing per locus and per population deviations from Hardy-Weinberg expectations, while Fisher exact test and confidence intervals based on the Markov chain method evaluated the statistical significance of the results [20]. Where significant deficiencies of heterozygotes from Hardy-Weinberg expectations were found, the presence of a relatively high frequency of null alleles was suspected [36], and in this case the allele frequencies were adjusted following the correction proposed by Brookfield [7], using the software Micro-checker [48]. Differences between uncorrected and corrected allelic frequencies were assessed by an exact probability test, using SPSS program version 12.0 [45]. Linkage disequilibrium for each pair of loci across all populations was tested with the Fisher exact test and the sequential Bonferroni correction [42].

The population genetic structure of the overall samples was analysed for each locus with Wright's F-statistics [51,52], computed with 


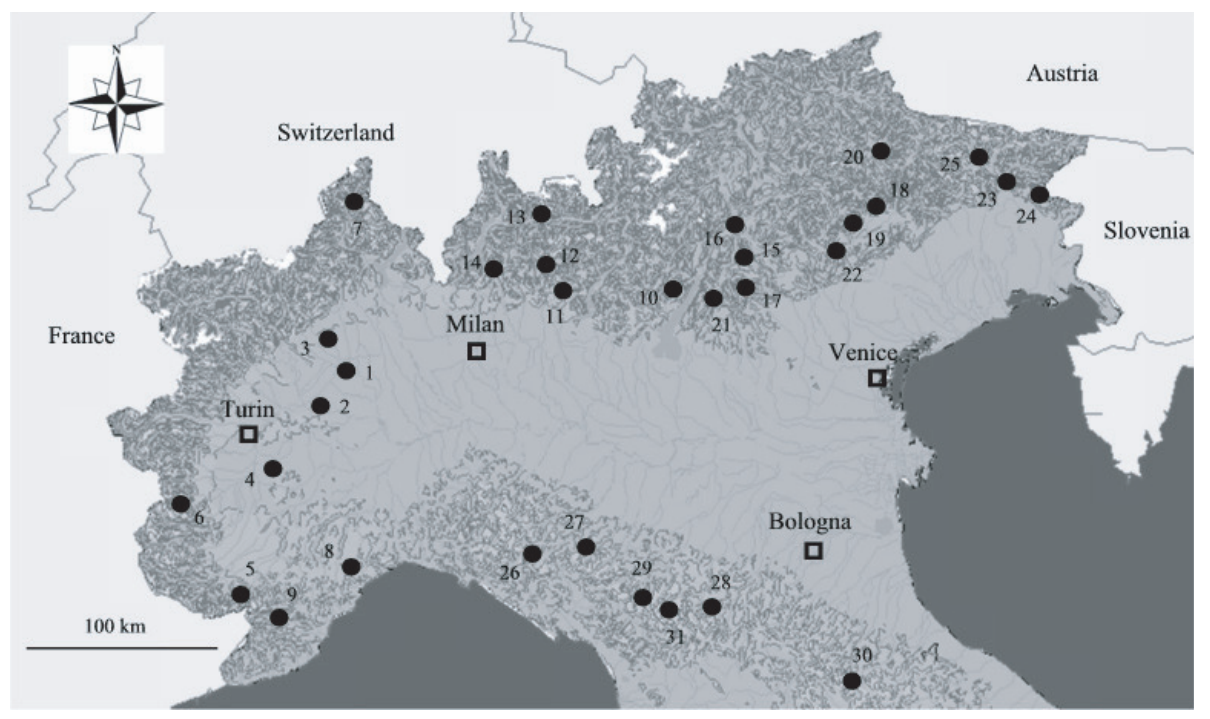

Figure 1. Geographical distribution of the 31 populations of common ash analysed in the study.

Weir and Cockerham [50] method and using the Fstat program. The analysis of molecular variance (AMOVA) [13] was performed to further study the genetic structure of populations using the Arlequin package version 3.0 [14]. The total molecular variance was partitioned into components due to differences among populations within pedo-climatic regions, among regions and within populations. The variance components and $F$ inbreeding indices were tested statistically by non-parametric randomization tests using 10000 permutations. Genetic differentiation between populations was estimated using pairwise $F_{\text {ST }}$ values given in form of a matrix, since pairwise $F_{\text {ST }}$ can be used as a short-term genetic distance between populations [ 40 , 44]. The null distribution of pairwise $F_{\mathrm{ST}}$ values under the hypothesis of no difference between the populations was tested by a permutation test of 10000 replicates. The genetic distance matrix [32] was computed with software Gendist of Phylip package version 3.6 [16], and the data obtained were used to construct the UPGMA (Unweighted Pair-Group Method using Arithmetic means) dendrogram, with the software Neighbor of the above mentioned package. The cophenetic values matrix was calculated from the tree matrix using the program Coph of Ntsys-pc version 2.1 [41]. The cophenetic matrix was used to evaluate goodness of fit for the cluster analysis by comparing it to genetic distances matrix (Mxcomp of Ntsys).

Isolation by distance among populations was assessed by computing $F_{\mathrm{ST}} /\left(1-F_{\mathrm{ST}}\right)$ ratios for each population pair using Genepop 3.4. A Mantel test [28] on the matrix of pairwise $F_{\mathrm{ST}} /\left(1-F_{\mathrm{ST}}\right)$ ratios and that of the logarithm of geographical distances (natural logarithm-scale) was performed to test isolation by distance adopting 1000 permutations.

\section{RESULTS}

\subsection{Definition of pedo-climatic regions}

The area where material was sampled was divided in regions that are homogeneous as regards as their geological, pedological and climatic characteristics. It was possible to define the following 5 regions:
- Po Valley (populations 1, 2, 3, 4);

- Ligurian Mountains (populations 5, 8, 9);

- Alps with crystalline soil (populations 6, 7, 13, 15, 16);

- Alps with calcareous soil (populations 10, 11, 12, 14, 17, $18,19,20,21,22,23,24,25)$;

- Apennines (populations 26, 27, 28, 29, 30, 31).

Population No. 30 (Campigna) was joined to the Apennine region, even though it is characterized by a Cambisol Regosol peculiar soil type with tertiary sedimentary rocks as parent material association. However, since it is the only representative of such a soil region it seemed appropriate to consider the Campigna stand together with the Apennine populations with which shares the climate type and the geographical localisation.

\subsection{Allelic diversity of microsatellite loci}

The total number of alleles at each locus and the size ranges of the PCR products corresponding to these alleles, are given in Table II; the data are compared with results reported in previous studies in France and Bulgaria. All six microsatellite loci employed in this study were highly polymorphic, displaying a high number of alleles (from 9 to 76 alleles per locus). The total number of alleles scored in 930 individuals over all loci was 253.

It was possible to detect 33 unique alleles, i.e. present only in one population. The frequency of these alleles was always very low, ranging from 0.033 to 0.111 . The distribution of unique alleles among microsatellites was unbiased, ranging from one (FEMSATL16) to eleven (FEMSATL19). The populations which displayed the highest number of such alleles were Lame del Sesia (5 private alleles) and Spazzacamini (3 private alleles), both belonging to the pedo-climatic region of Po Valley. 
Table II. Allelic diversity of the microsatellite loci scored in the present work, compared with French and Bulgarian results (number of alleles); n, not scored.

\begin{tabular}{|c|c|c|c|c|}
\hline \multirow[t]{2}{*}{ Microsatellite } & \multicolumn{2}{|c|}{ This study } & \multirow{2}{*}{$\begin{array}{l}\text { France } \\
\text { (Morand et al., 2002) }\end{array}$} & \multirow{2}{*}{$\begin{array}{l}\text { Bulgaria } \\
\text { (Heuertz et al., 2001) }\end{array}$} \\
\hline & Molecular weight (range in bp) & Number of alleles & & \\
\hline FEMSATL04 & $157-205$ & 32 & 37 & 50 \\
\hline FEMSATL10 & $143-338$ & 76 & $\mathrm{n}$ & $\mathrm{n}$ \\
\hline FEMSATL11 & $161-234$ & 42 & 40 & 32 \\
\hline FEMSATL12 & $147-261$ & 39 & $\mathrm{n}$ & 18 \\
\hline FEMSATL16 & $184-214$ & 9 & $\mathrm{n}$ & 10 \\
\hline FEMSATL19 & $142-238$ & 55 & 36 & 33 \\
\hline
\end{tabular}

Table III. Statistics of genetic variation within common ash populations at six microsatellite loci. $N$, mean number of alleles per locus; $R$, allelic richness average; $H_{\mathrm{o}}$, average observed heterozygosity; $H_{\mathrm{e}}$ average gene diversity; $F_{\text {IS }}$ average inbreeding coefficient. All given $F_{\text {IS }}$ values were highly significant $(P<0.001)$.

\begin{tabular}{llllll}
\hline Population & $N$ & $R$ & $H_{\mathrm{o}}$ & $H_{\mathrm{e}}$ & $F_{\mathrm{IS}}$ \\
\hline 1. Lame del Sesia & 14.5 & 10.64 & 0.516 & 0.778 & 0.337 \\
2. Partecipanza & 11.8 & 8.77 & 0.588 & 0.761 & 0.227 \\
3. Spazzacamini & 12.8 & 10.00 & 0.626 & 0.812 & 0.229 \\
4. Merlino & 11.5 & 9.33 & 0.531 & 0.752 & 0.294 \\
5. Pian delle Gorre & 12.7 & 9.58 & 0.525 & 0.834 & 0.371 \\
6. Oncino & 13.7 & 9.77 & 0.568 & 0.813 & 0.301 \\
7. Valle Divedro & 11.5 & 9.19 & 0.593 & 0.784 & 0.243 \\
8. Valle Bormida & 9.0 & 7.99 & 0.580 & 0.752 & 0.229 \\
9. Valle Tanaro & 13.7 & 10.09 & 0.669 & 0.825 & 0.188 \\
10. Archesane & 10.0 & 7.98 & 0.582 & 0.793 & 0.266 \\
11. Ponteranica & 11.5 & 8.15 & 0.587 & 0.770 & 0.237 \\
12. S. Pellegrino & 12.8 & 9.87 & 0.513 & 0.830 & 0.382 \\
13. Val Masino & 10.0 & 8.20 & 0.459 & 0.748 & 0.387 \\
14. Corni di Canzo & 14.5 & 10.66 & 0.584 & 0.841 & 0.305 \\
15. Valle Sella & 13.3 & 9.83 & 0.500 & 0.830 & 0.397 \\
16. Valle dei Mocheni & 11.7 & 9.16 & 0.615 & 0.832 & 0.261 \\
17. Contrada Sorto & 14.0 & 10.34 & 0.569 & 0.871 & 0.347 \\
18. Broz & 13.3 & 10.29 & 0.531 & 0.831 & 0.361 \\
19. Sedico & 11.7 & 8.86 & 0.586 & 0.811 & 0.277 \\
20. Peaio & 12.5 & 8.33 & 0.597 & 0.736 & 0.189 \\
21. Schivazzi & 13.5 & 9.96 & 0.508 & 0.798 & 0.363 \\
22. Fagarè & 14.3 & 10.50 & 0.640 & 0.837 & 0.235 \\
23. Chianei & 14.5 & 10.46 & 0.646 & 0.854 & 0.244 \\
24. Ponte Vittorio & 12.3 & 9.72 & 0.598 & 0.838 & 0.286 \\
25. Preone & 12.2 & 9.11 & 0.656 & 0.846 & 0.225 \\
26. Alta val Ceno & 9.7 & 7.68 & 0.618 & 0.802 & 0.230 \\
27. Monte Valoria & 14.0 & 9.13 & 0.488 & 0.726 & 0.328 \\
28. Valle Reno & 10.0 & 8.29 & 0.577 & 0.740 & 0.220 \\
29. S.Anna Pelago & 13.0 & 9.47 & 0.594 & 0.759 & 0.217 \\
30. Campigna & 11.8 & 9.01 & 0.512 & 0.815 & 0.372 \\
31. Abetone & 10.5 & 8.09 & 0.546 & 0.727 & 0.249 \\
Overall mean & 12.3 & 9.30 & 0.571 & 0.798 & 0.284 \\
(standard deviation) & $(1.6)$ & $(0.89)$ & $(0.052)$ & $(0.041)$ & $0.064)$ \\
\hline & & & & &
\end{tabular}

\subsection{Genetic variation within populations}

Statistics on the genetic diversity within populations are shown in Table III. High polymorphism was found within populations, since on average more than 12 alleles were observed per locus $(N=12.3)$. The highest value was found in Lame del Sesia, Corni di Canzo and Chianei (14.5) and the lowest in Valle Bormida (9.0). Allelic richness $R$ ranged from 7.68 (Alta val Ceno) to 10.66 (Corni di Canzo), with a mean of 9.30. Apennine populations in general showed lower values of genetic diversity, although the differences between the mean values of pedo-climatic regions were not statistically significant (data not shown).

The probability that two randomly sampled alleles in a given population were different was close to $80 \%\left(H_{\mathrm{e}}=\right.$ 0.798). The observed heterozygosity $\left(H_{\mathrm{o}}=0.571\right)$ was much lower than the expected heterozygosity $\left(H_{\mathrm{e}}\right)$ indicating a significant positive mean inbreeding coefficient. Significant departures from Hardy-Weinberg equilibrium were observed at most loci in all populations, detecting a significant homozygote excess $\left(F_{\text {IS }}\right.$ ranging from 0.188 , Valle Tanaro, to 0.397 , Valle Sella, with a mean of 0.284). Among the possible factors that may account for the excess of homozygotes is the presence of null alleles, which may lead to biased estimates of genetic variation and differentiation based on allele frequencies. Allele frequency distribution adjusted after the Brookfield correction was not significantly different $(P<0.001)$ from the uncorrected distribution for the six loci considered. The average estimated frequency of null alleles was 0.14 , and ranged from 0.05 (FEMSATL19) to 0.25 (FEMSATL12).

Inaccurate results may also be generated by linkage disequilibrium. In our study however no significant linkage disequilibrium was detected between different genotypes at any of the different loci.

\subsection{Genetic differentiation among populations and regions}

Population structure was analysed by calculating the following inbreeding indices: $F_{\mathrm{IT}}$, which represents the overall fixation index; $F_{\text {IS }}$, which represents the fixation index due to non-random mating within populations; and $F_{\mathrm{ST}}$, which represents the fixation index due to population subdivision. $F$ statistic estimates calculated per populations and per locus, 
Table IV. $F$ statistics of genetic diversity and differentiation among 31 populations of common ash from Italy at six microsatellite loci. $F_{\text {IT }}$, overall inbreeding; $F_{\text {IS }}$, average inbreeding coefficient; $F_{\mathrm{ST}}$ differentiation among populations.

\begin{tabular}{lccc}
\hline Locus & $F_{\text {IT }}$ & $F_{\text {IS }}$ & $F_{\text {ST }}$ \\
\hline FEMSATL04 & 0.304 & 0.274 & 0.041 \\
FEMSATL10 & 0.367 & 0.332 & 0.053 \\
FEMSATL11 & 0.339 & 0.312 & 0.040 \\
FEMSATL12 & 0.519 & 0.481 & 0.073 \\
FEMSATL16 & 0.240 & 0.191 & 0.060 \\
FEMSATL19 & 0.107 & 0.078 & 0.031 \\
Multilocus estimates & 0.321 & 0.286 & 0.049 \\
Permutation test & $P<0.001$ & $P<0.001$ & $P<0.001$ \\
\hline
\end{tabular}

Table V. Analysis of molecular variance (AMOVA) within and among the populations joined according to pedo-climatic regions.

\begin{tabular}{lcccccc}
\hline Source of variation & df & $\begin{array}{c}\text { Sum } \\
\text { of squares }\end{array}$ & $\begin{array}{c}\text { Variance } \\
\text { components }\end{array}$ & $\begin{array}{c}\text { Percentage } \\
\text { of variation }\end{array}$ & $P$ \\
\hline Among regions & 4 & 33.535 & 0.011 & 0.61 & $<0.001$ \\
Among populations & 26 & 138.959 & 0.069 & 3.76 & $<0.001$ \\
within regions & & & & & \\
Within populations & 1443 & 2528.853 & 1.759 & 95.63 & $<0.001$ \\
Total & 1473 & 2701.347 & 1.839 & 100.00 & - \\
\hline
\end{tabular}

according to Weir and Cockerham's [50], are reported in Table IV. The $F_{\text {IS }}$ values provided evidence that inbreeding occurs within populations, ranging from 0.078 (FEMSATL19) to 0.481 (FEMSATL12), with a mean value of $0.286(P<0.001)$. The total inbreeding estimate $\left(F_{\mathrm{IT}}\right)$ showed a significant deficit of heterozygotes $(P<0.001)$ for all loci, ranging from 0.107 (FEMSATL19) to 0.519 (FEMSATL12), with a mean value of 0.321 . Most of genetic diversity was found within populations, while only a small amount of the variability occurred among populations $\left(F_{\mathrm{ST}}=0.049, P<0.001\right)$. The $F_{\mathrm{ST}}$ values per locus ranged from 0.031 (FEMSATL19) to 0.073 (FEMSATL12), and all $F_{\mathrm{ST}}$ estimates were significantly different from zero.

The analysis of molecular variance (AMOVA) revealed that $0.61 \%$ of the genetic variation was found among pedo-climatic regions, whereas $3.76 \%$ was due to differences among populations within regions and $95.63 \%$ was detected within populations (Tab. V). All the different statistics were significant for the null hypothesis of no differentiation after 10000 random permutations.

The genetic divergence between populations was further investigated by computing a pairwise $F_{\mathrm{ST}}$ matrix. Multilocus $F_{\text {ST }}$ values varied between 0.001 (Fagarè and Spazzacamini) and 0.104 (Campigna and Valle Tanaro) (data not shown). Almost all pairwise $F_{\mathrm{ST}}$ values were significantly greater than zero, confirming the presence of a slight, although significant, amount of population structuring in Italian common ash populations.
The UPGMA dendrogram (Fig. 2) confirmed the presence of differentiation between populations as well as a certain degree of structuring. The cophenetic correlation coefficient gave a value of $r=0.807(P<0.001)$, suggesting the goodness of fit for the cluster analysis. In particular, populations from Ligurian Mountain, and the majority of those belonging to Po Valley and Apennines showed a clear tendency to group together. Exceptions are represented by populations 3 for Po Valley and 30 for Apennine. On the other hand, no clear structure was observed for populations from the two regions in which the Alpine area was divided according to soil characteristics.

The correlation between genetic diversity, expressed as $F_{\mathrm{ST}} /\left(1-F_{\mathrm{ST}}\right)$ ratio for pairs of populations, and the logarithm of distances expressed in units of $5 \mathrm{~km}$, did not show the typical pattern of isolation by distance and did not suggest any evidence of a relationship between the two factors (Fig. 3).

\section{DISCUSSION}

The principal aim of this study was to assess the level and the distribution of genetic variation of common ash in Italy, in order to get essential knowledge for planning activities in the fields of plant propagation and the conservation of genetic resources. Species such as common ash that do not have strong habitat specificity and are continuously distributed are expected to have more within-populations diversity than those with strong habitat preference and a scattered distribution. The level of variation is also associated with the dispersion of pollen by wind.

Genetic diversity assessed with microsatellite markers in our sample of populations of Fraxinus excelsior from Italy was considerable: the observed number of alleles per locus ranged from 9 to 76 (average per population 12.3), and the average gene diversity $\left(H_{\mathrm{e}}\right)$ was as high as 0.840 . These values are comparable with those of an analogous study carried on 10 common ash populations in Bulgaria, where 12.4 alleles per locus were scored and $H_{\mathrm{e}}$ was 0.731 [22]. The similarity of genetic variability levels between Italian and Bulgarian populations is remarkable, and palaeontological data support the hypothesis that southeastern Europe has been an important refuge for plant species, including common ash, during the Quaternary glacial period $[9,34,49]$. In this region species are therefore expected to preserve high level of intraspecific biodiversity. Italian populations thus appear to constitute an important gene reservoir, not limited to the Apennine region (another possible refuge area), where indeed the level of genetic variation is slightly lower than in other areas. Our results support the hypothesis of Heuertz et al. [24] concerning the possibility that other Italian areas (for instance eastern Alps) were also important refuges for common ash during the Quaternary glacial periods.

Populations of common ash from Italy are strongly inbred $\left(F_{\text {IT }}=0.321\right.$ and $\left.F_{\text {IS }}=0.284\right)$. This result is in agreement with that reported by Morand et al. [29] for 12 French populations analysed at five microsatellite loci. The study on Bulgarian populations also detected a significant excess of homozygotes, although at a lower level $\left(F_{\text {IS }}=0.014\right)$ [22]. 


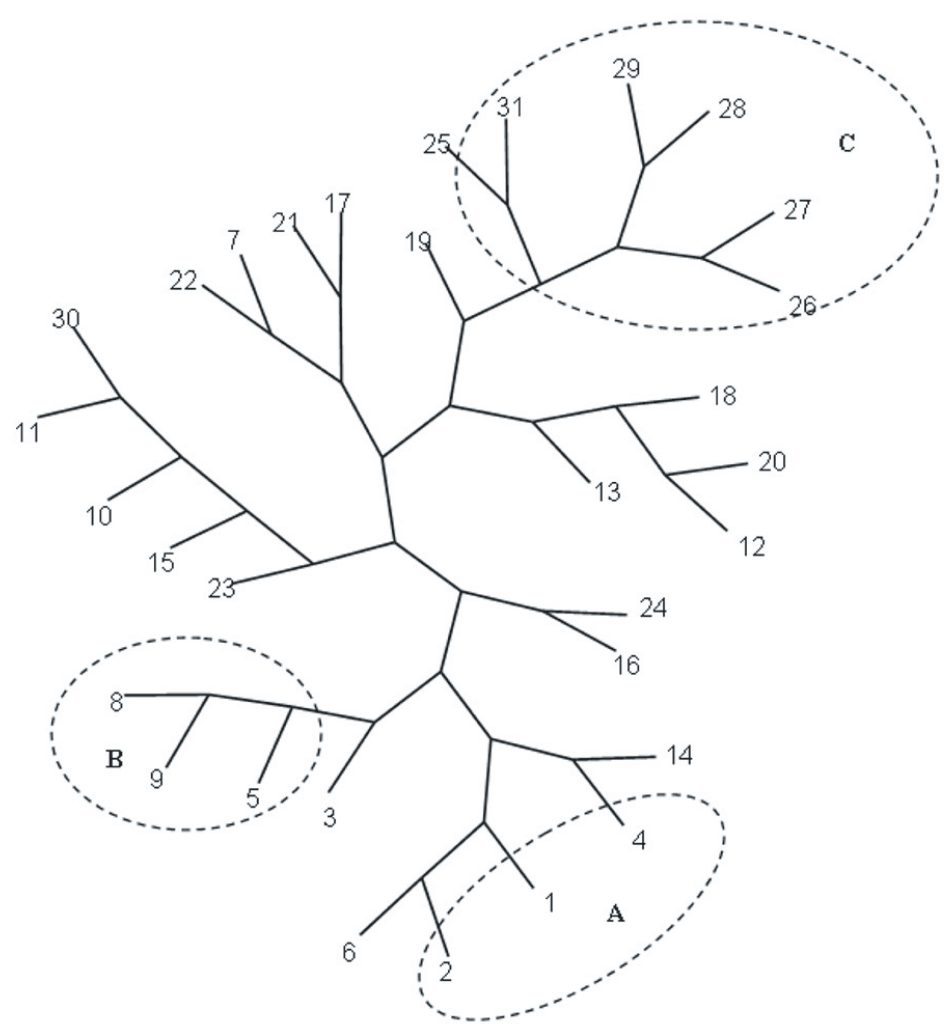

Figure 2. UPGMA dendrogram based on genetic distances between populations. Dotted lines group populations from the same pedo-climatic region (A, Po valley; B, Ligurian Mountains; C, Apennines). All populations outside the circles belong to the two pedo-climatic regions of Alps, with the exception of population 3 (Po Valley) and 30 (Apennines).

The deficiency of heterozygotes, as indicated by positive values of inbreeding coefficient, could be due to many factors, among which is the artificial reintroduction of genotypes obtained from seeds produced by a limited number of parental individuals in nurseries. We can exclude this hypothesis however, since all the populations considered in the study are natural and no afforestation of common ash occurred in the past. In forest species in general the level of heterozygosity tends to increase in mature age classes due to selection against homozygotes $[3,15,43,53]$. In a previous study on ash populations from northwestern Italy, we found that homozygosity, estimated through allozyme markers, does indeed decrease with the age of populations [2]. Morand et al. [29] confirmed the excess of homozygosites, although the mean inbreeding coefficient showed a different pattern and increased from seed (0.163) to adult tree (0.292) stages. Furthermore these authors did not observe any inbreeding depression. Additional studies are needed to better clarify if the peculiar mating system of common ash induces genetic characteristics of the populations different from the majority of other forest species. Another probable explanation for the excess of homozygotes is the presence of null alleles, which are common in microsatellite markers [8]. On the other hand, Morand et al. [29] and Morand-Prieur et al. [30] carried out test crosses and obtained the expected Mendelian segregations for some of the loci used in our study (FEMSATL04, FEMSATL11 and FEMSATL19), thereby excluding the presence of null alleles. We also have to bear in mind that FEMSATL12 is likely to generate null alleles, as already suggested by Heuertz et al. [22] who found a very high estimate of inbreeding coefficient $\left(F_{\text {IS }}=0.697\right)$ and the lack of successful amplification in a large proportion of individuals (up to 35\%). The question of null alleles of FEMSATL12 could well be answered using different primers, as recently suggested by Gérard et al. [18]. Heuertz et al. [25] also indicated the presence of null alleles in FEMSATL16, although no unreliable amplification reactions were observed. For FEMSATL10 no data have been found in the literature. We did however find about $18 \%$ of individuals lacking amplification, and it therefore seems appropriate to hypothesize the presence of null alleles, although only the establishment of a test cross could give definitive confirmation. At any rate, FEMSATL10 showed the highest frequency of hypothetical null homozygotes, the data of other markers ranging from 0.10 (FEMSATL04) to 0.16 (FEMSATL12). Differences between observed allelic frequencies and those corrected according to Brookfield [7] were not significant, suggesting that the possible presence of null alleles does not bias the estimates of population genetic parameters. It is also possible to assume the presence of a Wahlund effect, that is the structuring of the populations in subunits within which mating is more probable. This does not seem to be the case of our populations, since we collected material from plants usually at a distance of about 


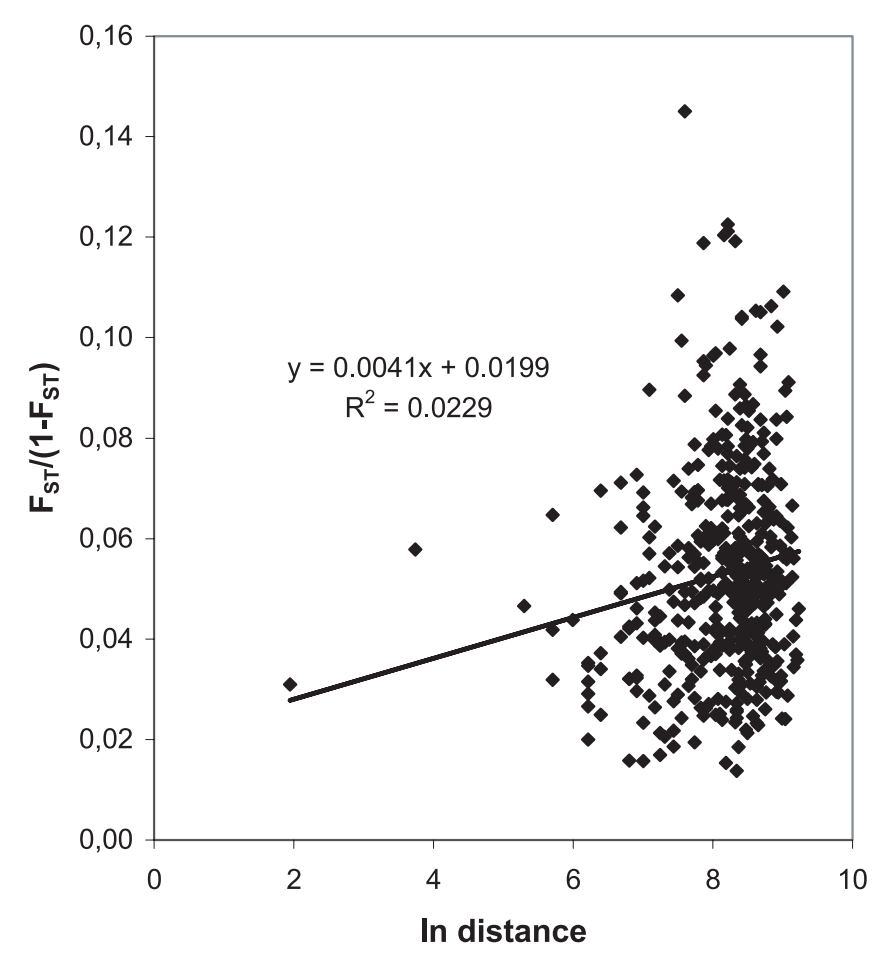

Figure 3. Graph of isolation by distance among populations assessed on the matrix of pairwise $F_{\mathrm{ST}} /\left(1-F_{\mathrm{ST}}\right)$ ratios and the logarithm of geographical distances.

$50 \mathrm{~m}$ from one another, and this should exclude the presence of any significant substructure. A further possible explanation of the excess of homozygotes is self-fertilization and biparental inbreeding, i.e. mating between related individuals. This appears to be unlikely in a species characterised by a such high degree of dioecy as common ash: however self-fertilisation has been observed in controlled crosses performed in France [30] as well as in Sweden and UK [17]. In the latter experiment however selfed seeds showed clear symptoms of inbreeding depression, which makes the survival of such seeds in natural conditions highly unlikely.

In the production of reproductive material, the level of inbreeding appears to be of utmost importance, since heterozygotes are in fact more resistant to environmental stresses [31, 46]. Therefore, in the choice of stands to be used for high quality seed production the homozygosity level should be taken into consideration, in order to avoid the negative effect of inbreeding on seed quality.

The overall pattern of genetic divergence among the populations studied reflects a story of short-term separation and consistent gene flow. Low levels of genetic differentiation are typical of species such as common ash and other forest trees, characterised by wide and relatively regular distribution, wide pollen dispersion and a high rate of outcrossing. Our populations thus share a single gene pool, and there is no evidence of any barriers likely to restrict gene flow between them. It should also be kept in mind that the last glacial period, and the consequent reinvasion of plants, occurred about 10000 years ago, a period too short to allow environmental selection and genetic drift to cause significant population divergence. Our $F_{\text {ST }}$ value $(0.049)$ is lower than that found in the Bulgarian study (0.087) [22], where differentiation between regions was also slightly higher than ours $\left(F_{\mathrm{RT}}=0.018\right.$, that is about $21 \%$ of total genetic diversity). Regions from Bulgaria however are geographically more separated than ours, and this could explain the higher genetic divergence between them. Further confirmation comes from the pattern of isolation by distance, that was significant in the Bulgarian study but not in ours. This result is not surprising, due to the peculiar characteristics of the area investigated. Pedo-climatic regions have in most cases a lengthwise shape, so that populations from different regions are often spatially closer than populations belonging to the same region. Furthermore, it is probable that gene flow, mainly considered to be by pollen diffusion, does not necessarily follow the shortest distance, due to the clearing for agricultural purposes affecting almost all of Po Valley. The few residual plain forests that still survive are isolated from each other, and in most cases this prevents gene exchange between them. Therefore, the most probable pathway of gene flow occurs within the areas located at the lower levels of the mountain chains, where the distribution of common ash and other forest trees is much more regular and almost continuous.

In spite of the low value of $F_{\mathrm{ST}}$ it was still possible to observe a pattern of population genetic differentiation. Three pedo-climatic regions were clearly defined in the dendrogram, although two of them lacked one population each. Concerning the Po Valley (characterized by peculiar soil type and climatic conditions), the population most differentiated is Spazzacamini (No. 3) which is located at higher altitude and closer to the Alpine region. All the Apennine populations cluster together, with the exception of Campigna (No. 30), which is indeed located in an area with different soil conditions and was included in this group only for reasons of convenience. The three populations from the Ligurian Mountains cluster together, suggesting an effect of soil type: in fact the climate is common to the alpine regions. However, in case of the Alps the soil type appears to be less important, since populations from the two sectors, characterized by different soils, were intermingled in different parts of the dendrogram.

\section{CONCLUSIONS}

Common ash populations from Italy showed a high level of genetic variability, similar to those detected in Bulgaria which is one of the most important refuge areas for the species. The preservation of such diversity therefore appears a goal to be vigorously pursued, adopting the most appropriate strategy of forest management.

Populations of common ash showed a considerable excess of homozygotes, a result which is consistent with findings obtained by other authors for the same species. Although several hypothesis can be proposed (presence of null alleles, self-fertilization or mating between related individuals, age of analysed plants, the Wahlund effect) none of them appear plausible to fully explain such a high value of inbreeding. It is likely therefore that any of the proposed explanations plays 
a role in determining the peculiar genetic structure of Italian common ash populations, although further study is needed to improve our knowledge of the situation.

Genetic differentiation among populations was slight, and in many cases it was possible to observe a pattern of genetic divergence coherent with pedo-climatic characteristics of the area where the plants grow, although some populations growing in the same region showed a quite different genetic structure.

The results of the study contribute to a better understanding of our knowledge of genetic variation of common ash in Italy, so making for more efficient programmes aimed at the preservation of the biodiversity. Furthermore our results give useful indications of how to plan for more rational planning of the management of reproductive material. According to the European Council Directive 1999/105/CE, forest reproductive material falling into the "source-identified" and "selected" categories should be used only within the Region of Provenance where it originated. The transfer of material from one Region to another should be avoided, due to possible problems associated with adaptability. Although our results did not show a significant effect of altitude on genetic characteristics of the stands it seems appropriate, as a precaution, to also consider this parameter in the frame of germplasm transfer, as provided for by European Directive. The identification of Regions of Provenance is therefore a basic aspect for a rational management of activities linked with forest trees propagation, including afforestation and in situ genetic preservation.

Acknowledgements: The work was funded by the Agency for Environmental Protection and Technical Services (APAT), Department of Nature Protection, Rome.

\section{REFERENCES}

[1] Bacles C.F.E., Burczyk J., Lowe A.J., Ennos R.A., Historical and contemporary mating patterns in remnant populations of the forest tree Fraxinus excelsior L., Evolution 59 (2005) 979-990.

[2] Belletti P., Monteleone I., Frassino maggiore, in: Calvo E., Fedrigol M., Vaiani L. (Eds.), Caratterizzazione genetica di popolazioni forestali della Lombardia. Regione Lombardia, Azienda Regionale delle Foreste, Milano, 2002, pp. 44-48.

[3] Belletti P., Monteleone I., Ferrazzini D., Genetic variability at allozyme markers, in sycamore (Acer pseudopatanus L.), populations from north-western Italy, Can. J. For. Res. (2007) (in press).

[4] Boshier D., Amaral W., Threats to forest ecosystems and challenges for the conservation and sustainable use of forest genetic resources, in: Vinceti B., Amaral W., Meilleur B. (Eds.), Challenges in managing forest genetic resources for livelihoods, IPGRI, Rome, 2004, pp. 7-22.

[5] Boshier D., Stewart J., How local is local? Identifying the scale of adaptative variation in ash (Fraxinus excelsior L.): results from the nursery, Forestry 78 (2005) 135-143.

[6] Brachet S., Jubier M.F., Richard M., Jung-Muller B., FrascariaLacoste N., Rapid identification of microsatellite loci using 5' anchored PCR in the common ash Fraxinus excelsior L., Mol. Ecol. 8 (1999) 160-163.

[7] Brookfield J.F.Y., A simple new method for estimating null allele frequency from heterozygote deficiency, Mol. Ecol. 5 (1996) 453455 .
[8] Bruford M.W., Ciofi C., Funk S.M., Characteristics of microsatellites, in: Karp A., Isaac P.G., Ingram D.S. (Eds.), Molecular Tools for Screening Biodiversity, Chapman \& Hall, London, 1998, pp. 202-205.

[9] Comes H.P., Kadereit J.W., The effect of Quaternary climatic changes on plant distribution and evolution, Trends Plant Sci. 3 (1998) 432-438.

[10] Cundall E.P., Cahalan C.M., Connolly T., Early results of ash (Fraxinus excelsior L.) provenance trials at sites in England and Wales, Forestry 76 (2003) 385-399.

[11] Eriksson G., Global warming and gene conservation of Noble Hardwoods, in: Turok J., Jensen J., Palmberg-Lerche C., Rusanen M., Russell K., de Vries S., Lipman E. (Eds.), Noble Hardwood Network - Report of the Third Meeting, 13-16 June 1998, Sagadi, Estonia, International Plant Genetic Resources Institute, Rome, 1999, pp. 98-112.

[12] European Commission, Georeferenced soil database of Europe, Manual of procedures, Version 1.0, EUR 18092 EN, 1999.

[13] Excoffier L., Smouse P.E., Quattro J.M., Analysis of Molecular Variance Inferred From Metric Distances Among DNA Haplotypes: Application to Human Mitochondrial DNA Restriction Data, Genetics 131 (1992) 479-491.

[14] Excoffier L., Laval G., Schneider S., Arlequin (version 3.0): An integrated software package for population genetics data analysis, Evol. Bioinf. Online 1 (2005) 47-50.

[15] Farris M.A., Mitton J.B., Population density, outcrossing rate, and heterozygosity superiority in ponderosa pine, Evolution 38 (1984) 1151-1154.

[16] Felsenstein J., PHYLIP: Phylogeny Inference Package, Version 3.6. (2004) http://evolution.genetics.washington.edu/phylip/doc/ main.html.

[17] FRAXIGEN, Ash species in Europe: biological characteristics and practical guidelines for sustainable use, Oxford Forestry Institute, University of Oxford, U.K., 2005.

[18] Gérard P.R., Fernandez M.J.F., Frascaria-Lacoste N., Temporal cline in a hybrid zone population between Fraxinus excelsior L. and F. angustifolia Valh, Mol. Ecol. (2006) in press.

[19] Goudet J., FSTAT (Version 1.2): a computer program to calculate $F$-statistics, J. Hered. 86 (1995) 485-486.

[20] Guo S.W., Thompson E.A., Performing the exact test of HardyWeinberg proportion for multiple alleles, Biometrics 48 (1992) 361-372.

[21] Herzog S., Krabel D., Preserving genetic resources: concepts and silvicoltural consequences on some European genera of Fagaceae, Forest Snow and Landscape Research 75 (2000) 205-217.

[22] Heuertz M., Hausman J.F., Tsvetkov I., Frascaria-Lacoste N., Vekemans X., Assessment of genetic structure with and among Bulgarian populations of the common ash (Fraxinus excelsior L.), Mol. Ecol. 10 (2001) 1615-1623.

[23] Heuertz M., Vekemans X., Hausman J.F., Palada M., Hardy O.J., Estimating seed versus pollen dispersal from spatial genetic structure in the common ash, Mol. Ecol. 12 (2003) 2483-2495.

[24] Heuertz M., Fineschi S., Anzidei M., Pastorelli R., Salvani D., Paule L., Frascaria-Lacoste N., Hardy O.J., Vekemans X., Vendramin G.G., Chloroplast DNA variation and postglacial recolonization of common ash (Fraxinus excelsior L.) in Europe, Mol. Ecol. 13 (2004) 3437-3452.

[25] Heuertz M., Hausman J.F., Hardy O.J., Vendramin G.G., FrascariaLacoste N., Vekemans X., Nuclear microsatellites reveal contrasting patterns of genetic structure between western and southeastern European populations of the common ash (Fraxinus excelsior L.), Evolution 58 (2004) 976-988.

[26] Huntley B., Birks H.J.B., An Atlas of Past and Present Pollen Maps of Europe: 0-13 000 Years Ago, Cambridge University Press, Cambridge, 1983. 
[27] Lefort F., Brachet S., Frascaria-Lacoste N., Edwards K.J., Douglas G.C., Identification and characterization of microsatellite loci in ash (Fraxinus excelsior L.) and their conservation in the olive family (Oleaceae), Mol. Ecol. 8 (1999) 1088-1090.

[28] Mantel N., The detection of disease clustering and a generalized regression approach, Canc. Res. 27 (1967) 209-220.

[29] Morand M.E., Brachet S., Rossignol P., Dufour J., FrascariaLacoste N., A generalized heterozygote deficiency assessed with microsatellites in French common ash populations, Mol. Ecol. 11 (2002) 377-385.

[30] Morand-Prieur M.E., Raquin C., Shykoff A., Frascaria-Lacoste N., Males outcompete hermaphrodites for seed siring success in controlled crosses in polygamous Fraxinus excelsior (Oleaceae), Am. J. Bot. 90 (2003) 949-953.

[31] Namkoong G., Forest Genetics and Conservation in Europe, in: Turok J., Palmberg-Lerche C., Skrøppa T., Ouédraogo A.S. (Eds.) Conservation of forest genetic resources in Europe, International Plant for Genetic Resources Institute, Rome, 1998, pp. 3-10.

[32] Nei M., Genetics distance between populations, Am. Nat. 106 (1972) 282-292.

[33] Nei M., Molecular Evolutionary Genetics, Columbia University Press, New York, 1987

[34] Newton A.C., Allnutt T.R., Gillies A.C.M., Lowe A.J., Ennos R.A., Molecular phylogeography, intraspecific variation and the conservation of tree species, Trends Ecol. Evol. 14 (1999) 140-145.

[35] Palmberg-Lerche C., Conservation of forest biological diversity and forest genetic resources, in: Palmberg-Lerche P., Iversen P.A., Sigaud P. (Eds.), Forest Genetic Resources 29, Food and Agriculture Organization of the United Nations, Rome, 2001, 70 p.

[36] Pemberton J.M., Slate J., Bancroft D.R., Barrett J.A., Nonamplifying alleles at microsatellites loci: a caution for parentage and population studies, Mol. Ecol. 4 (1995) 249-252.

[37] Picard J.F., Contribution a l'étude de la biologie florale et de la fructification du Frêne commun (Fraxinus excelsior L.), Rev. For. Fr. 34 (1982) 97-107.

[38] Pliûra A., European long-term gene conservation strategies: Ash (Fraxinus spp.), in: Turok J., Jensen J., Palmeberg-Lerche C., Rusanen M., Russell K., de Vries S., Lipman E. (Eds.), Noble hardwoods network - Report of the third meeting, 13-16 June 1998, Sagadi, Estonia, International Plant Genetic Resources Institute, Rome, 1999, pp. 8-20.

[39] Raymond M., Rousset F., Genepop (version 1.2): population genetics software for exact tests and ecumenicism, J. Hered. 86 (1995) 248-249.
[40] Reynolds J., Weir B.S., Cockerham C.C., Estimation for the coancestry coefficient: basis for a short-term genetic distance, Genetics 105 (1983) 767-779.

[41] Rholf F.J., NTSYS-PC, Numerical taxonomy and multivariate analysis system, Version 2.1, Setauket, NY, USA, Exeter Publishing, 2000 .

[42] Rice W.R., Analyzing tables of statistical tests, Evolution 43 (1989) 223-225.

[43] Rossi P., Vendramin G.G., Giannini R., Estimation of mating system parameters in two Italian natural populations of Fagus sylvatica, Can. J. For. Res. 26 (1996) 1187-1192.

[44] Slatkin M., A measure of population subdivision based on microsatellite allele frequencies, Genetics 139 (1995) 457-462.

[45] SPSS, SPSS Base 12.0 for Windows User's Guide, SPSS Inc., Chicago, IL, 2003.

[46] Tessier du Cros E., Màtyàs C., Kriebel H., Contribution of genetics to the sustained management of global forest resources Conclusions and recommendations, in: Màtyàs C. (Ed.), Forest genetics and sustainability, Forestry Sciences, Vol. 63, Kluwer Academic Publishers, Dordrecht, 1999, pp. 281-287.

[47] Toro M.A., Caballero A., Characterization and conservation of genetic diversity in subdivided populations, Phil. T. Roy. Soc. B. 1459 (2005) 1367-1378.

[48] Van Oosterhout C., Hutchinson W.F., Wills D.P.M., Shipley P., MICRO-CHECKER: software for identifying and correcting genotyping errors in microsatellite data, Mol. Ecol. Notes 40 (2004) 535538 .

[49] Vendramin G.G., Degen B., Petit R., Anzidei M., Madaghiele A., Ziegenhagen B., High level of variation at Abies alba chloroplast microsatellite loci in Europe, Mol. Ecol. 8 (1999) 1117-1126.

[50] Weir B.S., Cockerham C.C., Estimating $F$-statistics for the analysis of populations structure, Evolution 38 (1984) 1358-1370.

[51] Wright S., Systems of mating, Genetics 6 (1921) 111-178.

[52] Wright S., Evolution and the genetics of populations, The theory of gene frequency, Vol. 2, University of Chicago Press, Chicago, IL, 1969 .

[53] Yadzani R., Muona O., Rudin D., Szmidt A.E., Genetic structure of a Pinus sylvestris L. seed-tree stand and naturally regenerated understory, For. Sci. 31 (1986) 430-436. 